\title{
Intracranial epithelioid hemangioendothelioma causing subacute loss of vision
}

Figure $1 \quad$ Brain MRI

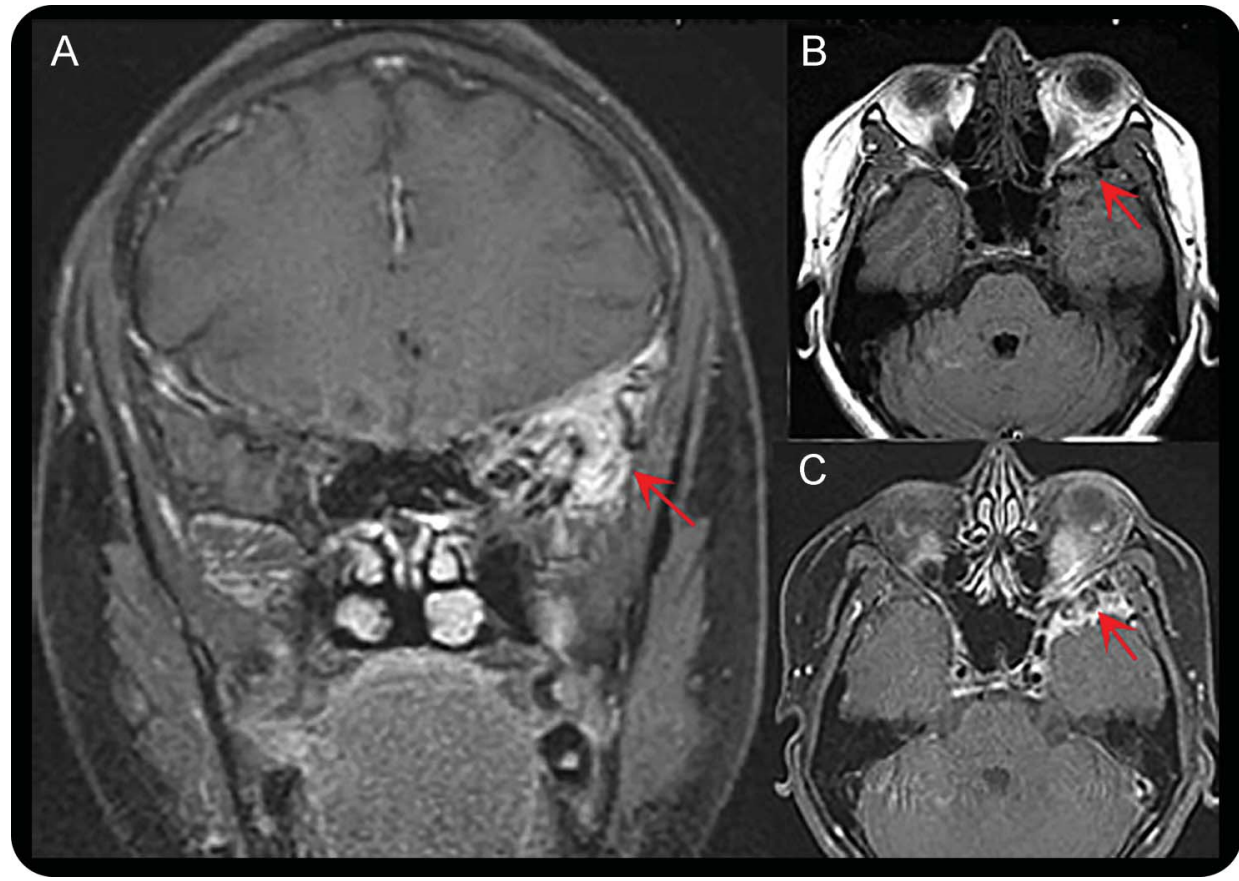

(A) Coronal T1 with contrast, (B) axial T1 without contrast, and (C) axial T1 with contrast showing left sphenoid mass (arrows).

A 37-year-old woman presented with left eye pain, headaches, and vision loss. MRI showed a left sphenoid mass, with optic nerve compression and proptosis (figure 1). The left eye had minimal reactivity to light, scleral erythema, and proptosis. A metastatic lesion or a lymphoma was suspected; however, pathology showed an epithelioid hemangioendothelioma (figure 2). There was no extracranial disease. Intracranial epithelioid hemangioendothelioma is rare, with around 40 reports. Thirty-two percent show local invasion, mortality is $15 \%, 24 \%$ recur, and $15 \%$ metastasize. ${ }^{1}$ It is associated with the WWTR1/CAMTA1 fusion protein. ${ }^{2}$ The treatment is surgery, with unclear roles for adjuvant therapy. ${ }^{1}$

Jose M. Pacheco, MD, J. Clay Goodman, MD, Jacob Mandel, MD

From the Department of Internal Medicine, Division of Hematology and Oncology (J.M.P.), Departments of Pathology \& Immunology and Neurology (J.C.G.), and Department of Neurology (J.M.), Baylor College of Medicine, Houston, TX.

Author contributions: Jose M. Pacheco: writing of manuscript, review of images, and literature review. J. Clay Goodman: review of pathology, preparation of pathology images, and review of manuscript. Jacob Mandel: review of images, preparation of images, and review of manuscript.

Study funding: No targeted funding.

Disclosure: The authors report no disclosures relevant to the manuscript. Go to Neurology.org for full disclosures.

Correspondence to Dr. Pacheco: jose.pacheco@bcm.edu

1. Zheng J, Liu L, Wang J, Wang S, Cao Y, Zhao J. Primary intracranial epithelioid hemangioendothelioma: a low-proliferation tumor exhibiting clinically malignant behavior. J Neurooncol 2012;110:119-127.

2. Tanas MR, Sboner A, Oliveira AM, et al. Identification of a disease-defining gene fusion in epithelioid hemangioendothelioma. Sci Transl Med 2011;3:98ra82. 


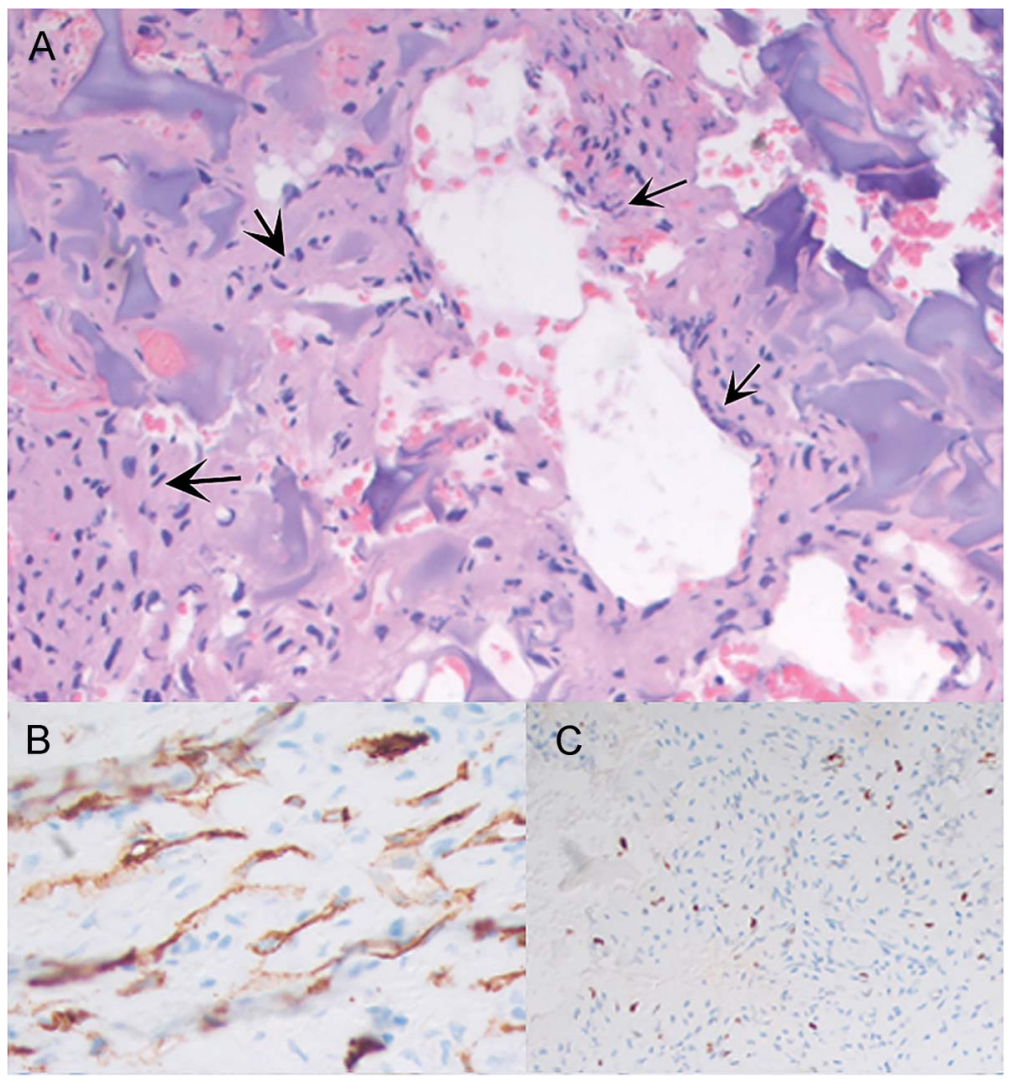

(A) Vascular channels with interspersed spindle cells (arrows). (B) Staining for CD34, one of the characteristic positive stains in this neoplasm. (C) Ki-67 showing low mitotic activity.

\section{Discover Altmetrics}

See real-time downloads and online activity for articles!

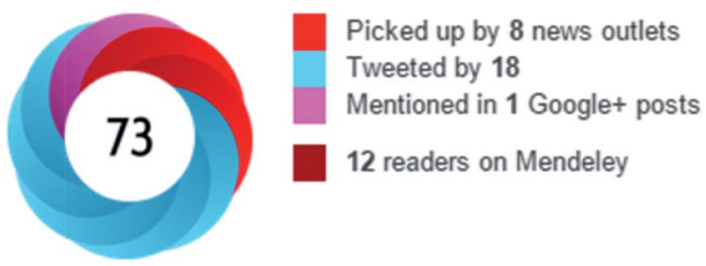

See more details

Authors and readers alike can view real-time data on articles including downloads and online activity across multiple sources. Click on the "Article Metrics" link in the right column of an article for details. To learn more about article metrics visit http://www.neurology.org/site/includefiles/article_usage.xhtml. 


\section{Neurology}

\section{Intracranial epithelioid hemangioendothelioma causing subacute loss of vision Jose M. Pacheco, J. Clay Goodman and Jacob Mandel Neurology 2015;85;735-736 \\ DOI 10.1212/WNL.0000000000001873}

This information is current as of August 24, 2015

\section{Updated Information \& Services}

References

Subspecialty Collections

Permissions \& Licensing

Reprints including high resolution figures, can be found at: http://n.neurology.org/content/85/8/735.full

This article cites 2 articles, 1 of which you can access for free at: http://n.neurology.org/content/85/8/735.full\#ref-list-1

This article, along with others on similar topics, appears in the following collection(s):

All Oncology

http://n.neurology.org/cgi/collection/all_oncology

Information about reproducing this article in parts (figures,tables) or in its entirety can be found online at:

http://www.neurology.org/about/about_the_journal\#permissions

Information about ordering reprints can be found online:

http://n.neurology.org/subscribers/advertise

Neurology ${ }^{\circledR}$ is the official journal of the American Academy of Neurology. Published continuously since 1951 , it is now a weekly with 48 issues per year. Copyright @ 2015 American Academy of Neurology. All rights reserved. Print ISSN: 0028-3878. Online ISSN: 1526-632X.

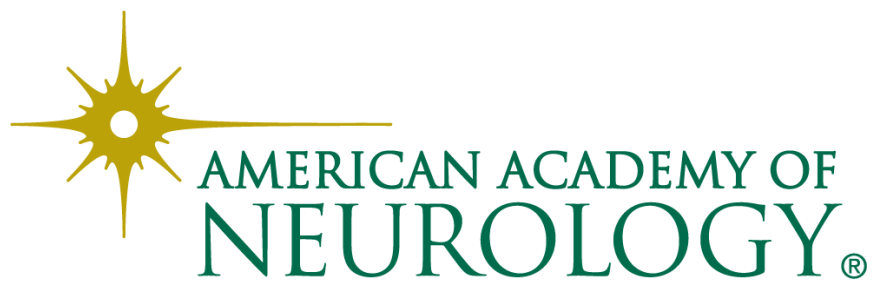

